\title{
Corporate Criminal Liability Practice in Criminal Action of Living Environment
}

\author{
Artur Pande Simbolon ${ }^{1 *}$, Pujiyono ${ }^{2}$, Purwoto $^{3}$ \\ \{artursimbolon@gmail.com ${ }^{* 1}$, pujiyono@live.undip.ac.id, purwoto@live.undip.ac.id ${ }^{3}$ \}
}

Fakultas Hukum, Universitas Diponegoro, Jl. Prof. H. Soedarto, S.H., Semarang, Indonesia $50275^{1}$

\begin{abstract}
Based on the adage societas delinquenre non potest, only humans can be convicted (natuurlijk persoon). Along with the times, the corporation can be charged with criminal liability. This research is needed in order to answer the problem of applying criminal liability to corporations in environmental crime. The approach method used is normative juridical using secondary data. The results of the study found that from the decisions examined, there were different views on the offenses committed by the corporation due to the variety of regulation of corporate criminal liability according to the type of criminal action. Therefore, the draft Criminal Code needs to be ratified immediately to eliminate law enforcement doubts caused by the differences in the regulation of corporate criminal liability in criminal law in Indonesia.
\end{abstract}

Keywords: Corporate Criminal Liability, Environmental Pollution Crime

\section{Introduction}

\subsection{Background}

Corporate crime triggers the modernization of law in Indonesia because it was initially held to the principle that legal entities (rechtpersonen) do not commit criminal acts and therefore legal entities cannot be convicted based on the legal adage "societas delinquenre non potest" or "university delinguere non potest". However, in line with the development of economic activity in parts of the world, there was a paradigm shift, that a crime can not be separated from the continuation of an activity and economic growth, in which corporations play a role in supporting or helping the smoothness of a crime. In line with the development and growth of this corporation, the impact can cause negative effects, therefore the position of the corporation has begun to shift from being a mere subject of civil law to the subject of criminal law.[1]

Even so, in many cases of environmental pollution involving corporations often the responsible party is the management.

For example, the case of environmental pollution carried out by PT Vision Land Semarang. In the case of unauthorized disposal of waste to the environment media by PT Vision Land Semarang, the defendant was Eom Dong Chul alias David Eom. The defendant worked at PT Vision Land Semarang as General Manager (GM).[2]

There are also cases of environmental pollution that have been proven by PT National Sago Prima (PT NSP) in Bengkalis, Riau. In the case of B3 waste committed by PT NSP, the defendant Ir. Erwin as branch manager of PT National Sago Prima (PT NSP), which operates 
in the Meranti Islands Regency, Riau Province. Besides Ir. Erwin who has been arrested, also as General Manager at PT. Sago Plantation NSP named Nowo Dwi Priyono alias Nowo was also arrested.[3]

This happens because there are still many people who consider that the corporation is a legal fiction, which therefore cannot be held responsible for criminal liability and cannot be punished, and in it there are innocent shareholders, who must bear the consequences of imposing criminal sanctions, in addition to stakeholders others must suffer the consequences.

The Expert Team for the Compilation of the New Criminal Code in its 1985 report stated the motivations for corporate responsibility are:

"By taking into account the development of the corporation, namely that it turns out that for certain offenses it was determined that the management as a convicted person was apparently not enough. In economic offenses it is not impossible that the fines imposed as punishment to the board are compared with the profits received by the corporation by committing the act, or the loss inflicted by the community, or suffered by its competitors, the profits and/or losses are greater than the fines imposed as a criminal.Accompanation of the management does not provide sufficient guarantees that the corporation will not once again commit acts that are prohibited by that law."[4]

From the description above, the writer tries to examine the corporal punishment in the case of environmental pollution crime, namely PT Kallista Alam. The company is engaged in plantations and agriculture, especially oil palm plantations, business, various industries, especially the palm oil processing industry.[5] PT Kallista Alam is proven to have violated Article 108 of Law Number 32 Of 2009 Regarding Environmental Protection and Management,[6] which is to clear land by burning land.

\subsection{Research Formulation}

1. What is the corporate responsibility policy in the legislation in the field of environmental pollution that applies in Indonesia?

2. What is the judge's consideration of PT Kallista Alam's criminal liability in the environmental crime?

\section{Research Method}

The approach method used is normative juridical. The research specifications used in this study are analytical descriptive. The data used is secondary data.

\section{Results}

\subsection{Provisions of the Laws and Regulations Regarding the Imposition of Liability for Environmental Pollution in Corporations}

Based on the sound of Article 59 of the Criminal Code, it can be concluded that the corporation is not known as a criminal law subject by the Criminal Code.[7] 
This is because the Criminal Code adheres to the principle of "non-potest delinguere universities" which basically states that only humans can be convicted.

However, the existence of Article 103 of the Criminal Code which becomes a bridge article provides an opportunity for laws outside the Criminal Code whose rules differ from the provisions in Book I of the Criminal Code, including the provisions regarding criminal liability. Law Number 32 of 2009 concerning Environmental Protection and Management based on Article 103 of the Criminal Code regulates other matters regarding criminal liability. In addition to humans, corporations can also be liable for criminal liability.

In addition to Article 1 Item (32) of Law Number 32 Of 2009 concerning Environmental Protection and Management, the subject of environmental criminal acts defines that every person is an individual or business entity, both legal and non-legal.

Business entities with legal entities consist of limited liability companies (PT), foundations and cooperatives. While business entities that do not have a legal entity consist of civil alliance, firm, and limited partnership (CV). These business entities may be subject to environmental crimes with the provisions in Article 116 through Article 120 of Law Number 32 Of 2009.

Article 116 of Law Number 32 of 2009 concerning Environmental Protection and Management explains the parties responsible for criminal acts committed by, for, or on behalf of business entities, criminal prosecution and criminal sanctions are imposed on:

a. Business entity, and /or;

b. A person giving the order to commit the crime or the person acting as the leader of the activity in the crime.

An environmental crime referring to Paragraph (1) is committed by a person, based on a work relationship or based on other relationships acting within the scope of work of a business entity, the criminal sanction is imposed on the order giver or leader in the crime without regard to the crime being carried out alone or together.

Then in Article 117 of Law Number 32 Of 2009 concerning Environmental Protection and Management explains that if a criminal charge is submitted to the issuing order or the leader of a criminal act as referred to in Article 116 Paragraph (1) letter b, the criminal threat that is imposed is in the form of imprisonment and fines aggravated by one third. Article 117 of Law Number 32 of 2009 concerning Environmental Protection and Management itself is based on the theory of vicarious liability, in which all elements of acts and intentions in environmental crime are in the corporation, but the management or other parties who responsible for being the party that receives criminal sanctions.

Business entity management is the party that carries out management of the relevant business entity in accordance with the articles of association. The management of business entities includes those in reality have authority and are involved in deciding policies or actions of business entities which can be qualified as criminal acts. Every individual who is appointed and has organizational or operational responsibility for specific behavior, or who has an obligation to prevent a violation by a business entity that is carrying out the obligation to carry out environmental protection and management as regulated in Article 68 of Law Number 32 of 2009, can criminal liability is held responsible for the occurrence of environmental crimes.[8]

A person whose role is a manager in a business entity organization must take action to prevent the occurrence of prohibited actions. However, when the role is not taken, it does not loose their position in the context of giving direction to the business entity's actions (which in fact the act was carried out by another employee). In this condition the person can also be said 
to be the lead person. A person can also be said to be factually leading a criminal act in a business entity/corporation if he is aware of the occurrence of the relevant crime, but he does not take steps to prevent the prohibited conduct and by accepting the circumstances of the prohibited act.[7]

Observing the formulation of Article 117 of Law Number 32 Of 2009 concerning Environmental Protection and Management which stipulates that a criminal threat to a giver of an order or a leader of a criminal offense is aggravated by one third, then the one who is prosecuted and sentenced is the management. The management of a business entity pursuant to Article 117 of Law Number 32 Of 2009 concerning Environmental Protection and Management is prosecuted and sentenced based on its personal responsibility or is the individual responsibility of the management. That is, if the Public Prosecutor indicts a person who manages a business entity by connecting Article 117 of Law Number 32 Of 2009 concerning Environmental Protection and Management in the indictment, then the accused is the person who is the executive (as an individual responsibility of the management of the business entity). The threat of punishment handed down to management (as an individual responsibility) in the form of prison and fines.

Article 118 of Law Number 32 of 2009 concerning Environmental Protection and Management explains that against the criminal acts as referred to in Article 116 Paragraph (1) letter A , criminal sanctions are imposed on business entities that are represented by management authorized to represent inside and outside the court is in accordance with the laws and regulations as the functional offender. Some experts consider that this Article is an alternative to Article 117 to convict management. As an example, Takdir Rahmadi considers Article 118 to constitute criminal charges against corporations using the theory of vicarious liability. This assumption is not quite right because Article 116 of Law Number 32 Of 2009 regarding Environmental Protection and Management itself has stated that corporations can be prosecuted and subject to criminal sanctions.

Article 118 of Law Number 32 Of 2009 concerning Environmental Protection and Management places more emphasis on the parties responsible for representing the corporation, because the corporation itself cannot be present at the hearing. For example, the rules in Article 98 Paragraph (1) of Law Number 40 Of 2007 concerning Limited Liability Companies where directors represent the company both in court and outside the court.[9] Looking at civil cases such as compensation, the directors clearly represent the company in the trial, but that does not mean that the directors compensate if the party is convicted of a crime. The Board of Directors only serves as the company's representative in administrative matters. Therefore, it can be said that the understanding that Article 118 of Law Number 32 Of 2009 concerning Environmental Protection and Management as a justification for imposing criminal responsibility on management is wrong.

Corporations themselves cannot be subject to the main penalties in the form of imprisonment. Corporations may only be subject to a principal criminal form of a fine. Therefore, Law Number 32 of 2009 concerning Environmental Protection and Management adds the types of crimes that can be imposed on corporations in the form of business entities through Article 119 of Law Number 32 of 2009 concerning Environmental Protection and Management which reads:

"In addition to criminal offenses as referred to in this Law, business entities may be subject to additional criminal or disciplinary actions in the form of:

a. Expropriation of Profits from Criminal Acts;

b. Closure of All or Part of Business Sites and/or Activities;

c. Corrections due to criminal acts; 
d. Obligation to do what is neglected without rights; And/or

e. Placement of Companies Under Capability for a maximum of 3 (three) years.

Within the Article 119 of Law Number 32 Of 2009 concerning Environmental Protection and Management, there are words and/or which means that the application of criminal sanctions can be normalized or accumulated, so as not to cause confusion for law enforcers in implementing these criminal sanctions. The procedure for applying the criminal sanction is stated in Article 120 of Law Number 32 Of 2009 concerning Environmental Protection and Management, which for criminal sanctions from points (a) to (d), the public prosecutor coordinates with the relevant agencies in carrying out the execution. Then for point (e), the company's capability is carried out by the government. It is not clear whether the central or regional government has the authority to carry out the allowance.

\subsection{Judges' Considerations in Imposing Criminal Liability for Corporations in Criminal Acts on Environmental Pollution in Decision Number 131/Pid.B/2013/PN.MBO jo. Decision Number 201/Pid/2014/PT BNA jo. and Decision Number 1554 K/Pid.Sus/2015 [10], [5], [11]}

\subsubsection{Position Case}

Convicted PT Kallista Alam is a company engaged in the field of Plantation, Industry, Supplier and Transportation. The defendant has an oil palm plantation area of \pm 1605 (one thousand six hundred five) Ha and has obtained a Plantation Business Permit in accordance with the Aceh Governor's letter No. 525/BP2T/5322/2011 dated August 25, 2011 concerning Business License for Oil Palm Plantation Plantations, the plantation area is included in the Leuser Ecosystem and National Strategic Areas which are determined based on Government Regulation No. 26 concerning National Spatial Planning.

In undertaking oil palm plantations, the clearing of oil palm areas has been carried out, namely land clearing and planting of oil palms for the plantation area of the Alue Geutah Division, the Gunung Kong Division, Division II, VII, VIII, IX, X of PT. Kalista Alam as planned in 2012 will be planted on land that is ready to be stacked or stacked, namely blocks A1, A2, A3, A5 and A7.

However, on Friday, March 23, 2012, a fire broke out at A2 Block VII Division VII of PT. Kalista Alam with an area of about 5 (five) hectares. The area is included in the area of the Suak Bahong plantation that has not yet been planted with oil palm but has been stacked, and a planting hole has been prepared.The fire originated from PT. Kalista Alam, which at the time the fire was burning into the A2 block garden land that had been done stacking but had not yet been planted, at that time the fire burned up the pile lanes (north-south) on the A2 block this fire lasted until Tuesday 27 March 2012 and no blackout attempts from PT. Kalista Alam.

The fire also repeated again, namely on Sunday, June 17, 2012 to Sunday, June 24, 2012 in Block E42B Division VIII covering \pm 8 (eight) Ha, at the time the fire was heading north, burning stack of stacking and bad oil palm plants ( the growth is stunted and the leaves are yellow).

From the results of the inspection also found that the oil palm plantation of PT. Kalista Alam has carried out land clearing activities on peatlands with a thickness of more than 3 meters and in areas that have been designated as national strategic areas protected by applicable laws and regulations, and has also carried out activities to prepare land by burning 
systematically and planned through omission against fires, especially in areas where land clearing is being carried out and this has been happening for years.

\subsubsection{Indictment}

Against the actions, the convicted is charged with a single indictment namely:

- Article 108 jo. Article 69 Paragraph (1) letter (h), Article 116 Paragraph (1) letter (a), Article 118, Article 119 of Law Number 32 of 2009 concerning Environmental Protection and Management and jo. Article 64 Paragraph (1) of the Criminal Code

- Article 108 of Law Number 32 Of 2009 reads:

Every person who burns land as referred to in Article 69 Paragraph (1) letter h, shall be sentenced to a maximum imprisonment of 3 (three) years and a maximum of 10 (ten) years and a fine of at least IDR 3,000,000,000.00 (three billion rupiah) and a maximum of IDR 10,000,000,000 (ten billion rupiah).

If the convicted person is a corporation, then it cannot be imposed with imprisonment, and can only be subject to fines and additional penalties for the corporation as stipulated in Article 119 of Law Number 32 Of 2009.

Article 69 Paragraph (1) letter (h) of Law Number 32 Of 2009 reads:

Everyone is prohibited from clearing land by burning.

This Article contains prohibitions or acts prohibited. If the offender is proven to have committed an offense for which the accused is subject to criminal sanctions. In the case of PT Kallista Alam, the criminal act charged was the burning of land in an effort to open up oil palm plantations in the city of Meulaboh, Nanggroe Aceh Darussalam.

\subsubsection{Decision of Meulaboh District Court Judge Number 131/Pid.B/2013/PN.MBO}

The Meulaboh District Court judge handed down the verdict to PT Kallista Alam with the following ruling:

1. To state the actions of the defendant PT. KALLISTA ALAM which have been proven legally and convincingly guilty of committing the crime of "ENVIRONMENTAL LIVING DONE";

2. Drop the criminal action against Defendant PT KALLISTA ALAM, therefore with a fine of IDR 3,000,000,000.00 (three billion rupiah)

\subsubsection{Judges' Considerations in the Meulaboh District Court Decision Number 131/Pid.B/2013/PN.MBO}

Below is a summary of the considerations of the Meulaboh District Court Judges in Decision Number 131/Pid.B/2013/PN.MBO regarding the types of offenses and corporate criminal liability, namely:

\section{a. Elements of Everyone}

Law Number 32 of 2009 concerning Environmental Protection and Management, a new terminology is used, "every person", which in general terms states that each person is an individual or a corporation, so as such there must be a person/humans as legal subjects 
charged with an act that is prohibited and threatened by law. In addition, based on the facts revealed at the trial, the Defendant has confirmed his identity as contained in the Prosecutor/Prosecutor's indictment, regarding the truth of the Defendant's identity has also been justified by witnesses at the trial, so that the Panel of Judges believes that in examining and hearing this case there was an error about the person who was accused as the Defendant, therefore everyone in this case was the Defendant named PT. Kalista Alam represented by its Director Subianto Rusid.

Although it is necessary to prove whether the Defendant has carried out a series of acts of conduct as charged by the Prosecutor/Public Prosecutor, if the Defendant has indeed carried out a series of acts of conduct that meet all the elements of the Article of the criminal law charged, then by itself the elements "Everyone" has been fulfilled that the Defendant is the perpetrator of the criminal act in this case.

\section{b. Elements of Opening a Land by Burning}

The panel of judges was of the opinion that in determining whether PT Kallista Alam cleared land by burning, it had to be related to whether it had caused damage to the land, in this case peatlands managed by the defendant PT. Kalista Alam.

The panel of judges also argued that according to Law Number 32 Of 2009 concerning environmental protection and management in Article 2 regarding the principle, the principle of prudence is regulated, so that thus the management of PT Kallista Alam's plantation is not careful and the defendant's employees and staff are unable extinguishing the fire, it must be stated that land clearing has been carried out by burning.

In the interview, Dr. Basuki Wasis also stated from the results of observations and analysis of soil samples in the laboratory that it is true that at the location of the study there had indeed been environmental destruction due to burning of peat soils in the creation of oil palm plantations.

Dr. Basuki Wasis stated from the results of observations and analysis of soil samples in the laboratory that it was true that at the research location there had indeed been environmental destruction due to burning of peat soils in the creation of oil palm plantations. The sample was taken by the investigator together with expert Prof. Bambang Hero Saharjo, M.Agr. in the location of the fire when conducting a ground check or field survey after observing the data of the host area in Aceh, especially in the PT Kallista Alam plantation. Therefore the panel of judges believes that this element was fulfilled by the defendant.

\section{c. Elements Performed By Legal Entities}

The panel of judges was of the opinion that a legal entity, namely an independent legal subject, was one of them a Limited Liability Company.

PT Kallista Alam itself was founded by Notary Liliani Handajawati Tamsil, SH Notary Deed Number: 18 dated March 11, 1980 PT Kalista Alam Limited Liability Company, which subsequently was changed based on Notary Sartono Simbolon, SH Deed Number: 05 dated August 4, 2008 Minutes of PT Kalista Meeting Nature, and changes by Notary Ny. Yanty Sulaiman Sihotang, SH Notary Deed Number: 06 dated October 4, 2011. PT Kallista Alam as a legal entity also has clear organs, namely management and commissioners, its shareholders and appoints Subianto Rusid as Director of the Company. Therefore the panel of judges believes that this element was fulfilled by the defendant.

d. The Elements of Some Acts that have Relationships are such that they are viewed as continuing actions 
The panel of judges is of the opinion that in this element some of the acts that were indicted against the Defendant must be of similar kind. The meaning of the word "some actions must have such a relationship" this relationship can be interpreted in various ways, for example due to the time equation, the place where the occurrence of some of these actions and so on, Hoge Raad interpreted "continued action" as actions the same type and at the same time are the implementation of the same purpose, an action which is continued is not enough if some of the acts are similar acts, but these actions must also be an implementation of the same purpose which is prohibited by the Law.

According to Memorie van toelichting (MvT) theoretically it is said that there is a continuing act (voortgezette handeling) when there is someone committing multiple actions. Each of these acts constitutes a crime or a violation and between the acts there is a relationship such that it must be seen as a continuing act, where "there is such a relationship" the criteria are:

1. There must be a decision of the will, which is directed at one object in a crime (object delict).

2. Each action must be of the same type.

3. The grace period between the acts is not too long.

Based on the facts revealed at the trial as considered in the previous elements. It turned out that the fire occurred on March 23, 2012 covering an area of 5 hectares in block A 2 of Division VII witnessed by witness Farwiza together with witness Suratman, there was no extinction and at that place was in a state empty, and fires from 17 June 2012 to 24 June 2012 covering an area of 8 hectares in Block E42B Division VIII.

In the second fire, even when expert Bambang Hero Saharjo came to the place there was no fire control/prevention system, did not have access to an easily traversed road in mobilization, the provision of sufficient funds in the fire prevention program.

Based on the description of the above considerations, the Panel of Judges is of the opinion that the element "Committing several acts that have a relationship so that they are seen as continuing actions" has been fulfilled in the Defendant's actions.

Based on the entire description of the above considerations, all elements of the Article as charged by the Prosecutor/Public Prosecutor in a single indictment have been fulfilled, so that the Tribunal has the confidence that the defendant has been legally proven and convincingly guilty of committing a criminal offense. CONTINUOUSLY “.

\section{Discussion}

\subsection{Discussion I}

In consideration of the Meulaboh District Court Panel of Judges, it is explained that in this case, the application of Article 116 Paragraph (1) letter a and Article 118 of Law Number 32 of 2009 can be done. The panel of judges considered that Law Number 32 of 2009 regulates corporate punishment, which is defined in Article 1 Item (32) of Law Number 32 of 2009, so that PT Kallista Alam as a defendant could be convicted of a criminal sentence.

The panel of judges also believes that the defendant is a subject of independent law, which is a limited liability company. The panel of judges also considered that PT Kallista Alam was a legal entity that had clear organs, namely the management and commissioners, its 
shareholders and appointed Subianto Rusid as the Company's Director. In this case it can be concluded that the panel of judges considers PT Kallista Alam as the subject of criminal law and the panel of judges identified the mens rea of management as the mens rea of PT Kallista Alam.

Judges' consideration in this matter is appropriate, that the imposition of criminal liability against corporations is regulated in Law Number 32 of 2009. The application of Article 116 and Article 118 of Law Number 32 of 2009 is in accordance with the theory of identification, which states that those who commit actus reus is a controlling person (directing mind or controlling mind) of the corporation, so the mens rea of directing mind can be identified as the corporation itself, which in this case is PT Kallista Alam.

\subsubsection{The Decision of the Banda Aceh High Court Judge Number 201/Pid/2014/PT. BNA}

The Banda Aceh High Court Judge handed down the verdict to PT Kallista Alam with the following ruling:

1. Receive an appeal request from the defendant PT Kalista Alam;

2. Improve the decision of the Meulaboh District Court, dated July 15, 2014 Number: 131/Pid.B/2013/PN.Mbo, just regarding the formulation of an ammunition/qualification of a criminal offense handed down to the defendant so that the sentence reads as follows;

1) Stating the defendant PT Kalista Alam has been proven legally and convincingly guilty "Doing Criminal Action Opening Lands for Plantation of Palm Oil by How to Damage the Environment."

2) Convicting a criminal against a defendant, therefore, with a criminal fine of IDR $3,000,000,000.00$ (three billion) rupiah.

3) Strengthening the decision of the Meulaboh District Court on July 15, 2014 Number: 131/Pod.B/2013/PN Mbo for the rest.

4) Imposing court fees on the defendant in two court levels, which are appealed at IDR 10,000 (ten thousand rupiah).

\subsubsection{Judges' Considerations in the Decision of the Banda Aceh High Court Number 201/Pid/2014/PT. BNA}

The Panel of Judges of the High Court carefully studied the legal considerations given by the District Court. The High Court agreed with the legal considerations of the first-rate Judge which in the decision that the defendant was proven legally and convincingly guilty of committing a crime as charged., However, the High Court was of the opinion that the formulation of an amar/the qualification (straafsfeit) of a criminal offense committed by the defendant. The High Court disagrees because the core of the criminal act in the indictment is opening up land for oil palm plantations by continuing to damage the environment, so that the District Court's decision must be improved, and the Judge's consideration the first tier was taken over and taken into consideration by the High Court itself in deciding this case in the appeal level.

Therefore, the Panel of Judges of the Court of Appeal took over the consideration of the first-rate Judge, so the Court of Appeal upheld the decision of the Meulaboh District Court on July 15, 2014 Number 131/Pid.B/2013/PN MBO, for the remainder of the petition for appeal.

\subsection{Discussion II}


In the consideration of the Banda Aceh High Court Panel of Judges, it was explained that PT Kallista Alam was considered as the perpetrators of land clearing by burning. This is different from the District Court Judge's decision which states that PT Kallista Alam allowed land burning to occur.

Judge's consideration in this matter is appropriate, because the offense in this case is not an offense of commissions. The panel of judges is based on Article 69 Paragraph (1) letter h of Law Number 32 Of 2009 which states that everyone is prohibited from clearing land by burning. The word "do" in the Article explains that the act must be done by the perpetrator, and not by another party, so it is not possible to allow delinquency. PT Kallista Alam, in this case benefited from the clearing of the land, and PT Kallista Alam was proven to have planned the burning based on the hotspots that appeared, only on dead and yellow palm land and land that had not yet been planted with palm seedlings. Article 116 Paragraph (1) letter a of Law Number 32 Of 2009 also stipulates that if an environmental criminal offense is committed by, for, or on behalf of a business entity, then the business entity may be prosecuted and subject to criminal sanctions. Then, it can be concluded that the imposition of corporate criminal liability can only be applied if an environmental criminal offense is committed by, for and on behalf of a corporation, so that in an environmental crime, it is not possible for a corporation to be convicted of a criminal offense.

\subsubsection{Decision of the Supreme Court Judge Number 1554 K/Pid.Sus/2015}

The Supreme Court Judge ruled in cassation with the ruling as follows:

1. Refuse an appeal request from the Appellant/Defendant: PT. The NATURAL KALLISTA;

2. Charge the Defendant to pay the court fee at this cassation level in the amount of IDR 2,500.00 (two thousand and five hundred rupiah).

\subsubsection{Judge Considerations in the Supreme Court Decision Number 1554 K/Pid.Sus/2015}

The panel of judges believes that corporate prosecution/prosecution as subjects of theoretical or normative criminal offenses is justified. Corporations whether incorporated or non-legal entities or humans as individuals are both legal subjects of the offender and can be held accountable and sanctioned both civil, criminal and administrative. As long as there are facts of the trial, it can be proven that there is a relationship between the corporation and the management of the corporation/director which is realized through actus reus and mens rea perpetrators. So, both legal subjects must be held responsible and sanctioned. As is the case in the a quo. Various theories that can be used justify the filing of prosecution and corporate punishment for example, identification theory, functional theory and so on;

\subsection{Discussion III}

The panel of judges is of the opinion that corporate criminal liability is justified by supporting consideration in and the decision of the Meulaboh District Court and the decision of the Banda Aceh High Court.

The panel of judges also argued that as long as there were facts in the trial, it could be proven that there was a relationship between the corporation and the management of the corporation/director which was realized through actus reus and mens rea perpetrators, both legal subjects must be held responsible and sanctioned. The consideration of the panel of judges strengthens the application of the theory of identification in the verdict of the 
Meulaboh District Court, that the corporation is seen as a separate entity from the subject of human criminal law. In addition, it can be said that the panel of judges at each level recognizes that the theory of identification is in Law Number 32 of 2009 concerning Environmental Protection and Management. Therefore, it can be concluded that the Supreme Court judge's decision was correct.

\section{Conclusion}

\subsection{Conclusion}

From the description, it can be concluded that:

1. In the applicable regulations in Indonesia, if an environmental criminal offense is committed by, for and on behalf of a business entity, those that will be prosecuted and sentenced are, namely:

a. Corporations and people who act as leaders of activities or who give orders to commit environmental crimes;

b. Corporations;

c. People who give orders or act as leaders of activities in criminal acts;

2. Judge's considerations on Decision Number 131/Pid.B/2013/PN.MBO, Decision Number 201/Pid/2014/PT BNA, and Decision Number $1554 \mathrm{~K} / \mathrm{Pid} . S u s / 2015$ have several differences and similarities. In the verdict of the District Court Judge, PT Kallista Alam was considered to have the same mens rea as the management of the corporation, which is characteristic of identification theory. Even so, District Court judges considered that the offense committed by PT Kallista Alam was an omission offense (ommisa). The panel of judges of the Banda Aceh High Court is of the opinion that Article 69 Paragraph (1) letter $\mathrm{H}$ does not constitute an offense for an ommisa, so it must be corrected. Whereas in the decision of the Supreme Court Judge, the panel of judges agreed with the decision of the District Court Judge Meulaboh and the decision of the Banda Aceh High Court Judge regarding the appointment of PT Kallista Alam as a convict; therefore, the decision of the Supreme Court Judge strengthened the decision of the Banda Aceh High Court Judge, and rejected the petition the appeal of the defendant.

\subsection{Suggestion}

There are several suggestions from the author regarding the issue of imposing criminal liability on corporations, including:

1. It is better for law enforcers in Indonesia to be more daring in convicting corporations. Law enforcers need to understand more about the theory of corporate punishment such as identification theory or theory of functional offenders. So, they are not too dependent on the vicarious liability theory which imposes criminal liability on the management, especially when the corporation causes great damage, and benefits from criminal acts.

2. It is recommended that the Criminal Code concept governing corporate criminal liability be ratified immediately, because the different corporate criminal penalties in each legislation can cause confusion for law enforcers in applying criminal penalties to the corporation. 


\section{References}

[1] M. Mulyadi and F. A. Surbakti, Politik Hukum Pidana Terhadap Kejahatan Korporasi. Medan: Sofmedia, 2010.

[2] R. J. Dayani and A. M. Pujiyono, "Pertanggungjawaban Pidana Korporasi terhadap Pembuangan Limbah ke Media Lingkungan Hidup tanpa Izin (Studi Kasus Putusan Pengadilan Negeri Ungaran No. 62/pid. sus/2013/pn. ung)," Diponegoro Law J., vol. 6, no. 1, pp. 1-15, 2016.

[3] RiauGreen.com, "Kasus Pencemaran Limbah B3 dan Karhutla Oleh PT NSP, Kejari Bengkalis Menangkan Kasasi dari Mahkamah Agung," 2016. [Online]. Available: http://riaugreen.com/view/Bengkalis/21769/Kasus-Pencemaran-Limbah-B3-danKarhutla-Oleh-PT-NSP--Kejari-Bengkalis-Menangkan-Kasasi-dari-MahkamahAgung-.html\#.Xv8cKij7TDc. [Accessed: 09-Aug-2018].

[4] Badan Pembinaan Hukum Nasional, Himpunan Laporan Hasil Pengkajian Bidang Hukum Pidana Tahun 1980-1981. Jakarta: BPHN, 1985.

[5] Decision of the Banda Aceh High Court Number 201/Pid/2014/PT.BNA. .

[6] Law Number 32 of 2009 concerning Environmental Protection and Management. .

[7] S. R. Sjahdeini, Ajaran Pemidanaan: Tindak Pidana Korporasi dan Seluk-Beluknya. Depok: Kencana, 2017.

[8] A. Syahrin, "Komentar atas Pasal 117 UUPPLH. Ilmu Hukum - Hukum Lingkungan Hukum Pidana," 2014. [Online]. Available: http://alviprofdr.blogspot.com/2014/07/komentar-pasal-117-uupplh.html\#more. [Accessed: 10-Dec-2019].

[9] Law Number 40 of 2007 concerning Limited Liability Companies. .

[10] Decision of Meulaboh District Court Number 131/Pid.B/2013/PN.MBO. .

[11] Decision of the Supreme Court Number 1554 K/Pid.Sus/2015. . 